\title{
Balancing of sulfur storage in maize seed
}

Yongrui Wu, Wenqin Wang and Joachim Messing ${ }^{*}$

\begin{abstract}
Background: A balanced composition of amino acids in seed flour is critical because of the demand on essential amino acids for nutrition. However, seed proteins in cereals like maize, the crop with the highest yield, are low in lysine, tryptophan, and methionine. Although supplementation with legumes like soybean can compensate lysine deficiency, both crops are also relatively low in methionine. Therefore, understanding the mechanism of methionine accumulation in the seed could be a basis for breeding cultivars with superior nutritional quality.

Results: In maize (Zea mays), the 22- and 19-kDa a-zeins are the most prominent storage proteins, nearly devoid of lysine and methionine. Although silencing synthesis of these proteins through RNA interference (RNAi) raises lysine levels in the seed, it fails to do so for methionine. Computational analysis of annotated gene models suggests that about $57 \%$ of all proteins exhibit a lysine content of more than $4 \%$, whereas the percentage of proteins with methionine above $4 \%$ is only around $8 \%$. To compensate for this low representation, maize seeds produce specialized storage proteins, the $15-\mathrm{kDa} \beta-, 18-\mathrm{kDa}$ and $10-\mathrm{kDa} \delta$-zeins, rich in methionine. However, they are expressed at variant levels in different inbred lines. A654, an inbred with null $\delta$-zein alleles, methionine levels are significantly lower than when the two intact $\delta$-zein alleles are introgressed. Further silencing of $\beta$-zein results in dramatic reduction in methionine levels, indicating that $\beta$ - and $\delta$-zeins are the main sink of methionine in maize seed. Overexpression of the 10-kDa $\delta$-zein can increase the methionine level, but protein analysis by SDS-PAGE shows that the increased methionine levels occur at least in part at the expense of cysteines present in $\beta$ - and $\gamma$-zeins. The reverse is true when $\beta$ - and $\gamma$-zein expression is silenced through RNAi, then 10-kDa $\delta$-zein accumulates to higher levels.

Conclusions: Because methionine receives the sulfur moiety from cysteine, it appears that when seed protein synthesis of cysteine-rich proteins is blocked, the synthesis of methionine-rich seed proteins is induced, probably at the translational level. The same is true, when methionine-rich proteins are overexpressed, synthesis of cysteine-rich proteins is reduced, probably also at the translational level. Although we only hypothesize a translational control of protein synthesis at this time, there are well known paradigms of how amino acid concentration can play a role in differential gene expression. The latter we think is largely controlled by the flux of reduced sulfur during plant growth.
\end{abstract}

Keywords: Sulfur, Methionine, Cysteine, RNAi, Nutrition and maize

\section{Background}

The main storage proteins in maize, also called zeins, are encoded by a multigene family and divided into four classes, i.e., $\alpha$ (19- and 22-kDa), $\gamma(50-, 27-$ and $16-\mathrm{kDa})$, $\beta(15-\mathrm{kDa})$ and $\delta(18-$ and $10-\mathrm{kDa})$ zeins. The general feature of all zein proteins in amino acid composition is that they are nearly lysine-free and very rich in glutamine and proline. However, each class is characteristic

\footnotetext{
* Correspondence: messing@waksman.rutgers.edu

Waksman Institute of Microbiology, Rutgers University, 190 Frelinghuysen Road, Piscataway, NJ 08854, USA
}

for their specific amino acid biases. The $\gamma$-zeins are abundant in cysteine, whereas $\delta$-zeins contain very high percentages of methionine [1,2]; $\beta$-zein is rich in both [3], whereas $\alpha$-zeins are devoid of them.

Breeders, maize geneticists, and molecular biologists have applied different strategies for generating maize inbreds with a balanced amino acid composition. High-lysine maize mutants with an opaque phenotype were identified based on the reduction of lysine-free $\alpha$-zein proteins and a compensatory increase of nonzein proteins [4]. For instance, opaque 2 (o2) lines of maize could contain nearly twice the amount of lysine

\section{Biomed Central}

(c) 2012 Wu et al.; licensee BioMed Central Ltd. This is an Open Access article distributed under the terms of the Creative Commons Attribution License (http://creativecommons.org/licenses/by/2.0), which permits unrestricted use, distribution, and reproduction in any medium, provided the original work is properly cited. 
compared to normal maize depending on the genetic background [5]. Still, $o 2$ maize could not be commercialized, because of its soft kernel texture and high sensitivities to insects and diseases. These adverse properties have been overcome with the introduction of quantitative trait loci (QTLs) that restore kernel hardness even with reduced levels of $\alpha$-zein proteins, which is recognized by the reversion of the opaque to normal seed phenotype. Because of these improvements, CYMMIT, who developed these maize lines, coined them Quality Protein Maize (QPM) [6]. Interestingly, the introgressed QTLs raise the expression of $\gamma$-zeins, which appear to be able to restore kernel hardness despite the reduced levels of $\alpha$-zeins [7]. Today, QPM has been introduced into 23 developing countries and grown over 10 million acres. Using dominant RNA interference (RNAi) to reduce $\alpha$-zeins instead of using the recessive $o 2$ mutation [8-10], can be used for advanced breeding of QPM and simplify its broader geographical application [10].

In developed countries, like the United States, QPM is not widely grown, because maize is not the main source of protein. As feed, maize is always supplemented with soybean, which contains sufficient levels of lysine. However, like maize, soybean is also deficient in methionine so that the animal diet is further fortified with chemically synthesized methionine, which is a racemic mixture of L- and D-methionine. This not only adds billions of dollars in cost every year, but the health impact of a racemic mixture has also been raised. Whereas the lack of lysine in $\alpha$-zeins can be compensated with increased levels of non-zein proteins in the seed, this shift cannot take place because of the low representation of sulfur amino acids in proteins in general. Moreover, o2 mutants have a reduced $\beta$-zein level [11], which in turn results in even lower methionine levels $[5,12]$. Because of these properties, a different strategy will be needed for increasing both lysine and methionine in maize to levels that avoid costly supplementation. However, unlike high-lysine mutants that have a visible phenotype, variation of methionine levels among inbred lines does not produce a visible phenotype. On the other hand, a biochemical seed germination screen, selecting for resistance to feedback inhibition of the biosynthesis of methionine, has been used to identify maize inbred BSSS53 having elevated levels of methionine in its seeds [12] that was due to the enhanced expression of the $10-\mathrm{kDa} \delta$ zein gene $[13,14]$. This link between seed methionine levels and expression of high-methionine storage proteins was further illustrated with the ectopic expression of $10-\mathrm{kDa} \delta$ - and $15-\mathrm{kDa} \beta$-zein genes in different species to study their stability and spatial deposition in heterologous system $[15,16]$. When the $10-\mathrm{kDa} \delta$-zein gene was overexpressed in maize, the methionine level was significantly increased, close to that of BSSS53 [17]. Other approaches that increase the synthesis or reduce the metabolism of methionine have also been exploited in other species [18-20].

Our hypothesis is that seed storage proteins serve as a sink for photosynthates. During their growth plants convert reduced elements of nitrogen and sulfur into amino acids using energy from photosynthesis. This scheme is easy to follow for reduced nitrogen based on the rebalancing that occurs when zeins are reduced and non-zeins are elevated [21]. However, the mechanism for the storage of sulfur-amino acids (cysteine or methionine) is less clear. Because seed proteins have evolved specialized proteins for cysteine and methionine accumulation and storage, we reasoned that knockdowns of different zein proteins through RNAi could shine new light on the reduced sulfur sink in the seed. Indeed, when we reduced protein rich in cysteine, protein with methionine is increased, consistent with their biochemical pathway.

\section{Results}

Comparison of amino acid composition in different zeins

Storage proteins are grouped into albumins, globulins, glutelins, and prolamins (the latter also called zeins in maize) based on their solubility in different solvents (Figure 1) [22]. Total maize storage proteins are made of more than $60 \%$ zeins, of which about $70 \%$ are $\alpha$-zeins [23]. The $\alpha$-zeins are lysine-free and also low in methionine with less than $1 \%$ (Table 1). The others are also deficient in lysine with the exception of the 50-kDa $\gamma$-zein. However, the $50-\mathrm{kDa} \gamma$-zein is expressed at very low levels and only contains $2.52 \%$ lysine (Table 1 ). Therefore, it does not contribute to total lysine levels in the seed in any significant way. In general, $\gamma$-zeins are abundant in cysteine and $\delta$-zeins in methionine, whereas $\beta$ zein is rich in both cysteine and methionine (Table 1). In B73 seed flour, the lysine, methionine and cysteine levels are $2.54 \%, 2.30 \%$ and $2.40 \%$, respectively (Table 1 ), all significantly lower than an average of $5 \%$, a level at which the 20- $\mathrm{L}$ amino acids would be balanced in composition from a nutritional point of view.

\section{The main sink of methionine in maize seed}

The contribution of the methionine-rich $\beta$ - and $\delta$-zeins to entire methionine levels in seed was evaluated in inbred A654 background (see Methods), because it carries natural null alleles of both 18 - and $10-\mathrm{kDa} \delta$-zein genes [14]. The absolute amino acid level $\left(\mathrm{AA}_{\mathrm{ab}}\right)$ is calculated by the amount of an amino acid in total seed flour, whereas the relative level $\left(\mathrm{AA}_{\mathrm{rel}}\right)$ is represented by the percentage of an amino acid in total protein. The latter determines the nutritional value of seed protein. 


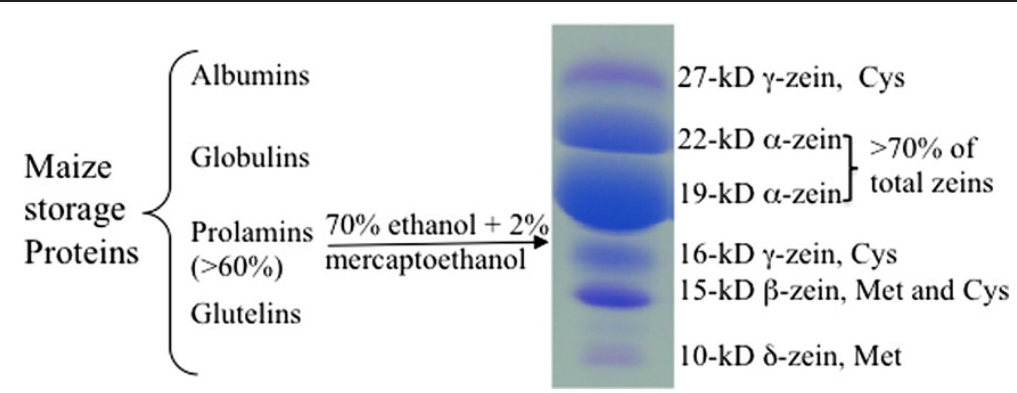

Figure 1 Classification of maize storage proteins. Protein isolation and gel electrophoresis are described under Methods.

Both Met $_{\text {ab }}$ and Met $_{\text {rel }}$ in A654 were about 20\% lower than those in A654- $\delta$ (Figure 2 and Table 2). After introduction of an RNAi event against $\beta$-zein in A654 (Figure 2), Met ${ }_{a b}$ and Met $_{\text {rel }}$ dropped even further to $38 \%$ and $40 \%$, respectively (Table 2 ), indicating that $\beta$ and $\delta$-zeins provided for methionine sinks in the seed. The specificity of this drop could be shown, when an RNAi event directed against $\gamma$-zeins was layered on top of the $\beta$-zein-RNAi. No further reduction in the Met $_{a b}$ and Met $_{\text {rel }}$ levels was noticed because $\gamma$-zeins are low in methionine. On the other hand, $\mathrm{Cys}_{\mathrm{ab}}$ and $\mathrm{Cys}_{\text {rel }}$ were dramatically decreased by $30 \%$ and $26 \%$, respectively (Table 2), indicating that $\gamma$ - and $\beta$-zeins provided for cysteine sinks in the seed. As expected, Lys $\mathrm{ab}_{\mathrm{ab}}$ and Lys were elevated in A654- $\beta \gamma R N A i$, since lysine-free zeins were suppressed, whereas proteins with normal lysine levels were elevated (Table 2).

The difference between nitrogen and methionine sinks The mechanism underlying the elevated lysine level in mutants with reduced accumulation of zeins is based on the fact that the reduction of lysine-free zeins is compensated by an increase of lysine-balanced non-zein proteins, resulting in nearly unchanged total protein level but enhanced lysine content (Figure 3). Because $\alpha$-zeins, which amount to about $70 \%$ of total zeins, are also deficient in methionine (Table 1), one would expect the same compensation mechanism for methionine. However, when 19 -and $22-\mathrm{kDa} \alpha$-zeins are knocked down with a double RNAi construct, neither Met ${ }_{\mathrm{ab}}$ nor Met $\mathrm{rel}_{\text {rel }}$ increase significantly, whereas Lys $_{a b}$ and Lys ${ }_{\text {rel }}$ were elevated by $59 \%$ and 56\%, respectively (Table 3). Therefore, either non-zeins are lower in methionine than lysine or a different mechanism controls the accumulation of methionine.

Currently, 36,201 protein-coding sequences with amino acids longer than 100 residues have been annotated in the maize database (http://www.plantgdb.org/ search $/ \mathrm{misc} /$ plantlistconstruction.php? mySpecies $=Z$ Zea\% 20 may s). By calculating the amino acid composition in each protein sequence, it was found that about $57 \%$ of the proteins have lysine residues above $4 \%$, whereas only about $8 \%$ of the proteins have methionine residues above $4 \%$. Proteins with both lysine and methionine above $4 \%$ only take up about $5 \%$ (Table 4). The relative lower content of methionine than lysine in predicted protein sequences then makes it plausible that raising the nonzein protein level cannot balance the methionine sink in the seed.

Table 1 Biased amino acid composition in zein protein sequences of different classes

\begin{tabular}{|c|c|c|c|c|c|c|c|}
\hline Zeins & MW (kDa) & Accession No. & Mature Peptide & Met\% & Cys\% & (Met + Cys\%) & Lys $\%$ \\
\hline \multirow[t]{4}{*}{$a$} & $22(f \mid 2)$ & L34340.1 & 241 & $0.00 \%$ & $0.41 \%$ & $0.41 \%$ & $0.00 \%$ \\
\hline & $19 \mathrm{~A}$ & BT034568.1 & 219 & $0.94 \%$ & $0.94 \%$ & $1.88 \%$ & $0.00 \%$ \\
\hline & $19 B$ & DQ244961.1 & 220 & $0.46 \%$ & $0.91 \%$ & $1.37 \%$ & $0.00 \%$ \\
\hline & $19 \mathrm{D}$ & BT061340.1 & 219 & $0.46 \%$ & $0.46 \%$ & $0.92 \%$ & $0.00 \%$ \\
\hline \multirow[t]{3}{*}{ Y } & 50 & AF371263 & 278 & $1.08 \%$ & $5.40 \%$ & $6.48 \%$ & $2.52 \%$ \\
\hline & 27 & AF371261 & 204 & $0.49 \%$ & $7.35 \%$ & $7.84 \%$ & $0.00 \%$ \\
\hline & 16 & AF371262 & 163 & $1.84 \%$ & $7.36 \%$ & $9.20 \%$ & $0.00 \%$ \\
\hline$\beta$ & 15 & AF371264 & 160 & $11.25 \%$ & $4.38 \%$ & $15.63 \%$ & $0.00 \%$ \\
\hline \multirow[t]{2}{*}{$\delta$} & 18 & AF371265 & 190 & $25.26 \%$ & $1.58 \%$ & $26.84 \%$ & $0.53 \%$ \\
\hline & 10 & AF371266 & 129 & $22.48 \%$ & $3.88 \%$ & $26.36 \%$ & $0.00 \%$ \\
\hline Total Protein ${ }^{a}$ & / & / & / & $2.30 \%$ & $2.40 \%$ & $4.70 \%$ & $2.54 \%$ \\
\hline
\end{tabular}

${ }^{\text {aData }}$ was measured from B73 seed flour. It was calculated by the percentage of an amino acid in total seed protein. 


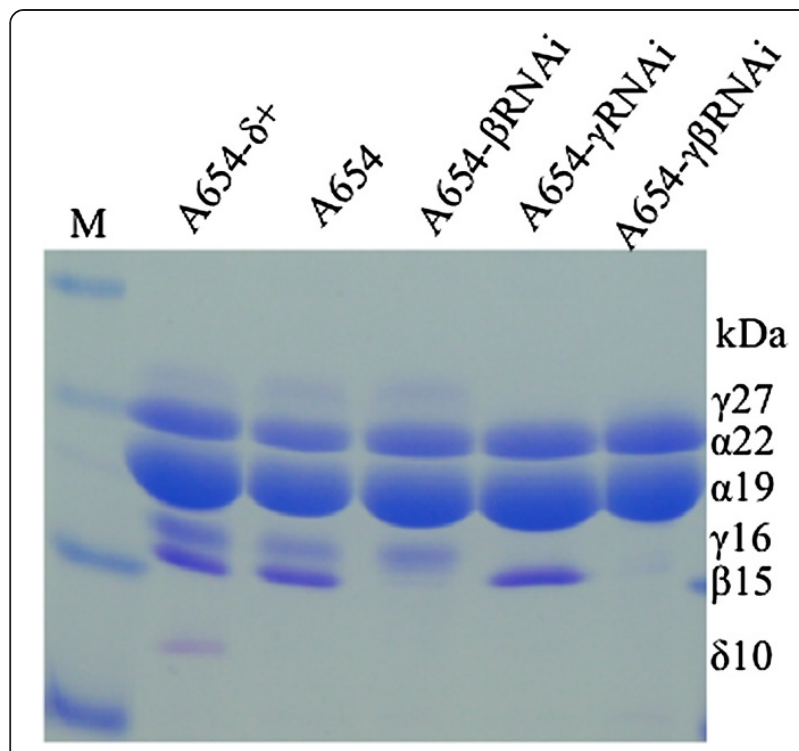

Figure 2 Zein accumulation pattern in inbred A654 and its derivative lines with intact $\delta$-zein alleles, $\beta R N A i, \gamma R N A i$ or both RNAis. Protein from $500 \mu \mathrm{g}$ of maize flour was loaded in each lane. M, protein markers from top to bottom being 37, 25, 20, 15 and $10 \mathrm{kDa}$. The size of each zein band is indicated with numbers in the "kDa" column.

\section{Linkage of high-methionine phenotype to suppression of cysteine-rich zeins}

Consistent with these results is the overexpression of the methionine-rich $10-\mathrm{kDa} \delta$-zein, the resultant transgene called Hi-Met, in which the methionine-rich $10-\mathrm{kDa} \delta$ zein was overexpressed under the control of the strong $27-\mathrm{kDa} \gamma$-zein promoter [17]. Western blot analysis, indeed, confirmed enhanced $10-\mathrm{kDa} \delta$-zein and total methionine levels [17]. We then could ask, whether elevated levels of the $\delta$-zein would induce any compensatory adjustment among other zeins. Therefore, total zeins were extracted from the $\mathrm{Hi}$-Met line and subjected to SDS-PAGE. Interestingly, the expression of the three cysteine-rich 27-kDa, 16-kDa $\gamma$ - and $15-\mathrm{kDa} \beta$-zeins was noticeably reduced in $\mathrm{Hi}-\mathrm{Met}$ seeds compared to nontransgenic controls, whereas the accumulation of the cysteine-poor $\alpha$-zeins was unchanged (Figure 4A). To examine whether the high $10-\mathrm{kDa} \delta$-zein level phenotype was genetically linked to the low expression of cysteine-

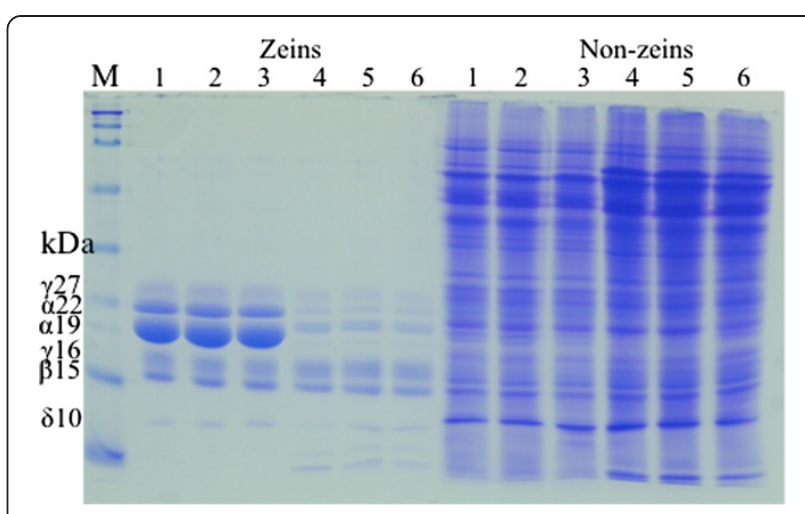

Figure 3 Protein accumulation pattern of seeds from the cross of B73 x P6z1CRNAi. Lanes 1-3, vitreous kernels with genotype $B 73 /-$; - /-; lanes 4-6, opaque kernels with genotype $B 73 /-$; P6z1RNAi/-. Zein and non-zein accumulation patterns of B73/-; -/and B73/-; P6z1RNAi/- were analyzed by 15\% SDS-PAGE. Protein from $500 \mu \mathrm{g}$ of maize flour was loaded in each lane. $M$, protein markers from top to bottom being 250, 150, 100, 75, 50, 37, 25, 20, 15 and $10 \mathrm{kDa}$. The size of each zein band is indicated with numbers in the " $\mathrm{kDa}$ " column.

rich zeins, a heterozygous transgenic plant ( $\mathrm{Hi}$-Met/-) was pollinated with B73 pollen. Single mature and developing seeds from 18-DAP were then analyzed for zein accumulation phenotypes (Figure $4 \mathrm{~B}$ and $\mathrm{C}$ ). Indeed, the high and low expression phenotypes of $10-\mathrm{kDa} \delta$-zein segregated with a ratio of $1: 1$. Furthermore, the high expression phenotype of the $10-\mathrm{kDa} \delta$-zein was linked to the suppression of $\gamma$ - and $\beta$-zeins (Figure $4 \mathrm{~B}$ and $C$ ).

As a control, we used the transgenic maize z1CRNAi event that reduced $22-\mathrm{kDa} \alpha$-zeins [8]. When a plant with the genotype $\mathrm{Hi}$-Met/-; z1CRNAi/- was pollinated with non-transgenic pollen of a High-II B x A cross, all progeny inheriting the transgene $\mathrm{Hi}$-Met accumulated reduced $\gamma$ - and $\beta$-zeins (Figure 4D). Therefore, the linkage between high $\delta$-zein and low $\beta$ - and $\gamma$-zeins was independent of the accumulation of $\alpha$-zeins.

\section{Linkage of knock-downs of cysteine-rich proteins to high-methionine phenotype}

Cysteine and methionine are the only two amino acids containing sulfur among the 20 L-amino acids. The enzymes cystathionine $\gamma$-synthase (CGS) and cystathionine $\beta$-synthase constitute the committing steps in the

Table 2 Amino acid composition in A654 and its different RNAi mutants

\begin{tabular}{|c|c|c|c|c|c|c|c|c|}
\hline \multirow[b]{2}{*}{ Amino acids } & \multicolumn{2}{|c|}{ A654- $\delta$} & \multicolumn{2}{|c|}{ A654 } & \multicolumn{2}{|c|}{ A654- $\beta$ RNAi } & \multicolumn{2}{|c|}{ A654- $\gamma \beta R N A i$} \\
\hline & $\mathrm{AA}_{\mathrm{ab}}$ & $\overline{A A_{\text {rel }}}$ & $\mathrm{AA}_{\mathrm{ab}}$ & $\mathrm{AA}_{\text {rel }}$ & $\mathrm{AA}_{\mathrm{ab}}$ & $\mathrm{AA}_{\mathrm{rel}}$ & $A A_{a b}$ & $\mathrm{AA}_{\text {rel }}$ \\
\hline Methionine & $0.24 \%$ & $2.42 \%$ & $0.20 \%$ & $2.09 \%$ & $0.15 \%$ & $1.44 \%$ & $0.13 \%$ & $1.40 \%$ \\
\hline Cysteine & $0.23 \%$ & $2.32 \%$ & $0.24 \%$ & $2.51 \%$ & $0.22 \%$ & $2.12 \%$ & $0.16 \%$ & $1.72 \%$ \\
\hline Lysine & $0.23 \%$ & $2.32 \%$ & $0.23 \%$ & $2.41 \%$ & $0.25 \%$ & $2.40 \%$ & $0.29 \%$ & $3.12 \%$ \\
\hline Total protein & \multicolumn{2}{|c|}{$9.90 \%$} & \multicolumn{2}{|c|}{$9.55 \%$} & \multicolumn{2}{|c|}{$10.40 \%$} & \multicolumn{2}{|c|}{$9.30 \%$} \\
\hline
\end{tabular}


Table 3 Amino acid composition in z1RNAi seed flour

\begin{tabular}{lllllll}
\hline \multirow{2}{*}{ Amino acids } & \multicolumn{2}{c}{$B 73 /-;-/-$} & & \multicolumn{2}{c}{$\mathbf{B 7 3 / - ;}$ P6z1RNAi/- } \\
\cline { 2 - 3 } \cline { 6 - 7 } Methionine & $\mathbf{A A}_{\mathbf{a b}}$ & $\mathbf{A A}_{\text {rel }}$ & & $\mathbf{A A}_{\mathbf{a b}}$ & $\mathbf{A A}_{\text {rel }}$ \\
Cysteine & $0.22 \%$ & $2.22 \%$ & & $0.24 \%$ & $2.38 \%$ \\
Lysine & $0.24 \%$ & $2.42 \%$ & & $0.24 \%$ & $2.38 \%$ \\
Total protein & $0.27 \%$ & $2.73 \%$ & & $0.43 \%$ & $4.26 \%$ \\
\hline
\end{tabular}

transfer of the sulfur moiety from cysteine to methionine. If the flux of sulfur to methionine were interrupted because of the increased use of cysteine in protein synthesis, would such a block slow the flux of sulfur to methionine and in turn reduce protein synthesis that consumes methionine? Indeed, using RNAi constructs that reduce the expression of cysteine-rich zeins [24], $\beta R N A i, \gamma R N A i$, and $\beta \gamma R N A i$ increase proportionally the accumulation of the $10-\mathrm{kDa} \delta$-zein (Figure $5 \mathrm{~A}$ ). In progeny from the cross of $\mathrm{B} 73$ or Mo17 $\mathrm{x} \beta R N A i /-; \gamma R N A i /-$ kernels with both RNAi genes accumulated the highest level of the $10-\mathrm{kDa} \delta$-zein. Progeny inheriting $\gamma R N A i$ or $\beta R N A i$ had an inverse proportional reduction of their mRNAs, correlating directly to their cysteine codons, respectively, whereas the progeny inheriting neither of the RNAi genes had the lowest $10-k D a ~ \delta$-zein levels (Figure $5 \mathrm{~B}$ and $\mathrm{C}$ ). Therefore, it appears that the level of $\beta$ and $\gamma$ - zeins can regulate the downstream methionine sink.

\section{Discussion}

\section{Layers of regulation of the methionine level in maize seeds}

Sulfur is one of the essential elements in organisms. During plant growth sulfur and nitrogen are taken up from the soil, reduced, and incorporated into amino acids during photosynthesis (Figure 6). The intermediate product is cysteine, from which methionine, the only other sulfur-containing amino acid, and a variety of other compounds receive reduced sulfur, such as SAM, glutathione and sulfolipids [19,25]. During senescence amino acids are transported to the seeds to capture the recovered energy from reduced nitrogen and sulfur for the next generation. Because seeds have low levels of free amino acids during desiccation, they have to store them in proteins compatible with seed dormancy and germination. It appears that reduced nitrogen can be sunk into proteins in general as protein synthesis can balance the reduction of storage proteins with nonstorage proteins. However, cysteine and methionine have to be captured in a different way because there are only two amino acids out of twenty with sulfur. Furthermore, these two amino acids, occur in rather low frequencies in proteins because of their specialized function, as one can see from the comparison of the presence of lysine, methionine, and cysteine in the coding regions of the maize genome (Table 4). Interestingly, maize embryos contain an average lysine but very low methionine level, whereas the endosperm has higher methionine but lower lysine levels [12]. Lysine levels have been substantially increased in the presence of RNAi directed against $\alpha$ zeins in endosperm [8-10,21], but methionine levels were only slightly elevated under these conditions (Table 3). In $o 2$, a mutant of the transcription factor that controls a subset of $\alpha$-zeins, the methionine level was even lower than that in normal inbreds [5,12], probably due to the decreased accumulation of $\beta$-zein.

Therefore, it is intriguing that methionine is concentrated in just a few storage proteins that are synthesized during endosperm development. However, maize seed methionine level varies among different inbred lines ranging from deficiency to a level that does not require fortification with the addition of synthetic methionine in animal feed [26]. Among the tested lines, BSSS53 contains the highest level of methionine. This trait in BSSS53 segregates with the expression levels of the 10$\mathrm{kDa} \delta$-zein, providing us with a genetic link between the $10-\mathrm{kDa} \delta$-zein gene and the methionine sink in the seed. Furthermore, different alleles of $\delta$-zein genes and alleles of regulators of $\delta$-zein genes that act posttranscriptionally rather than transcriptionally correlate with this trait directly $[2,14,27]$.

\section{Sulfate reduction limits further increase in methionine level}

Heterologous systems have already been used to investigate zeins as sulfur sink. For instance, the $15-\mathrm{kDa} \beta$-zein gene has been overexpressed in tobacco and a legume species alfalfa to evaluate its ability to store reduced sulfur if amino acid biosynthesis is raised [28,29], with the assumption that free methionine might be limiting in the synthesis of $\beta$-zein in alfalfa. Indeed, it was found that co-expression of the cystathionine $\gamma$-synthase from Arabidopsis thaliana (AtCGS) and the $\beta$-zein gene raised the levels of $\beta$-zein transcript and protein, confirming that $\beta$-zein was posttranscriptionally regulated by free methionine levels [29].

These observations in alfalfa are consistent with the results shown here that $\beta$-and $\delta$-zeins represent the

Table 4 Amino acid composition in maize protein sequences

\begin{tabular}{lcc}
\hline Total protein sequences & $\mathbf{3 6 , 2 0 1}$ & $\mathbf{1 0 0 \%}$ \\
\hline Lys $(>4 \%)$ & 20,509 & $57 \%$ \\
Met $(>4 \%)$ & 3,017 & $8 \%$ \\
Cys $(>4 \%)$ & 2,977 & $8 \%$ \\
(Lys Met) $(>4 \%)$ & 1,825 & $5 \%$ \\
\hline
\end{tabular}




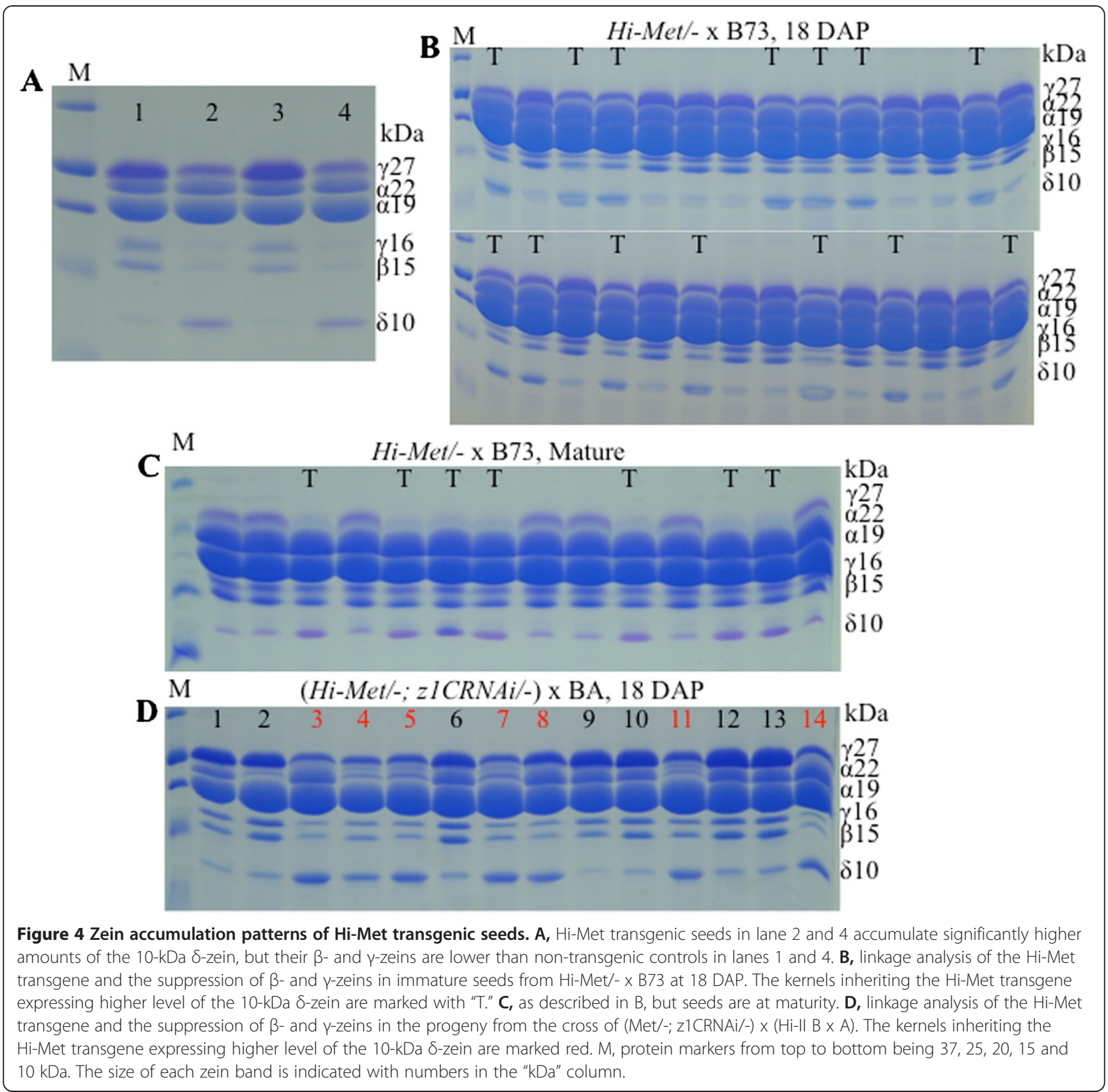

major sink of methionine, and $\beta$ - and $\gamma$-zeins of cysteine in maize seed (Table 2). Overexpression of the $10-\mathrm{kDa}$ $\delta$-zein increases the methionine level, but decreases $\beta$ and $\gamma$-zeins at the same time, which could trigger a threshold limit for raising methionine levels. In fact, although Hi-Met transgenic maize contained significantly higher methionine levels than the non-transgenic control, it did not exceed natural levels already found in inbred BSSS53 [17]. Moreover, if further increases of methionine levels would occur at the expense of cysteine due to $\beta$ - and $\gamma$-zeins (Figure 5), low levels of those would pose other seed deficiencies. Indeed, it has been shown that $\gamma$-zeins are essential for endosperm modification to maintain kernel vitreousness in quality protein maize (QPM) [7].

Because methionine is derived from cysteine, serving as the thiol moiety donor, it suggests that the bottleneck for the flux of sulfur is sulfur uptake and reduction to increase amino acid biosynthesis during plant growth. The combined action of three enzymes takes sulfur from the oxidation state +6 to -2 , catalyzed by ATP sulfurylase, APS reductase (APR) and sulfite reductase, respectively (Figure 6). The reduced sulfide then reacts with $\mathrm{O}$-acetylserine (OAS), forming the end product of assimilation of cysteine catalyzed by OAS thiol-lyase. OAS is formed by serine acetyltransferase (SAT). Cysteine not 


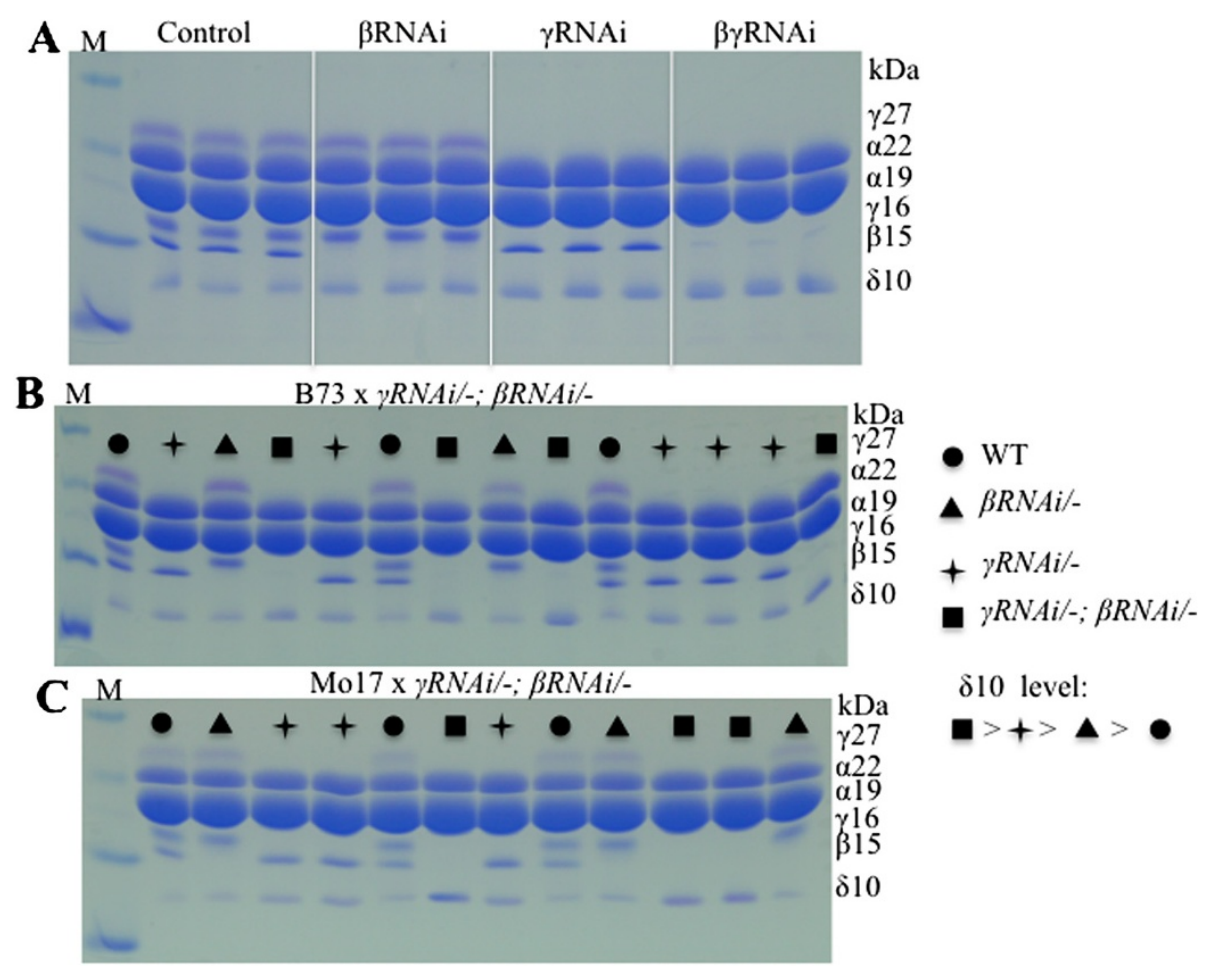

Figure 5 Increased accumulation of the 10-kDa $\delta$-zein in transgenic RNAi seeds. A, Comparison of the 10-kDa $\delta$-zein level in nontransgenic control, $\beta R N A i, \gamma R N A i$ and $\beta \gamma R N A i$ in Hi-ll background. B, linkage analysis of the 10-kDa $\delta$-zein level and RNAis in seeds from the cross of B73 $\times$ ץRNAi/-; $\beta R N A i /-$. C, linkage analysis of the 10-kDa $\delta$ - zein level and RNAis in seeds from the cross of Mo17 $\times$ YRNAi/-; $\beta R N A i /-$. Kernel genotypes are marked with different symbols. M, protein markers from top to bottom being 37, 25, 20, 15 and $10 \mathrm{kDa}$. The size of each zein band is indicated with numbers in the " $\mathrm{kDa}$ " column.

used in the synthesis of cysteine-rich proteins, like $\beta$ and $\gamma$-zeins, could flow into methionine and induce the translation and thereby the stability of the $10-\mathrm{kDa} \delta$-zein

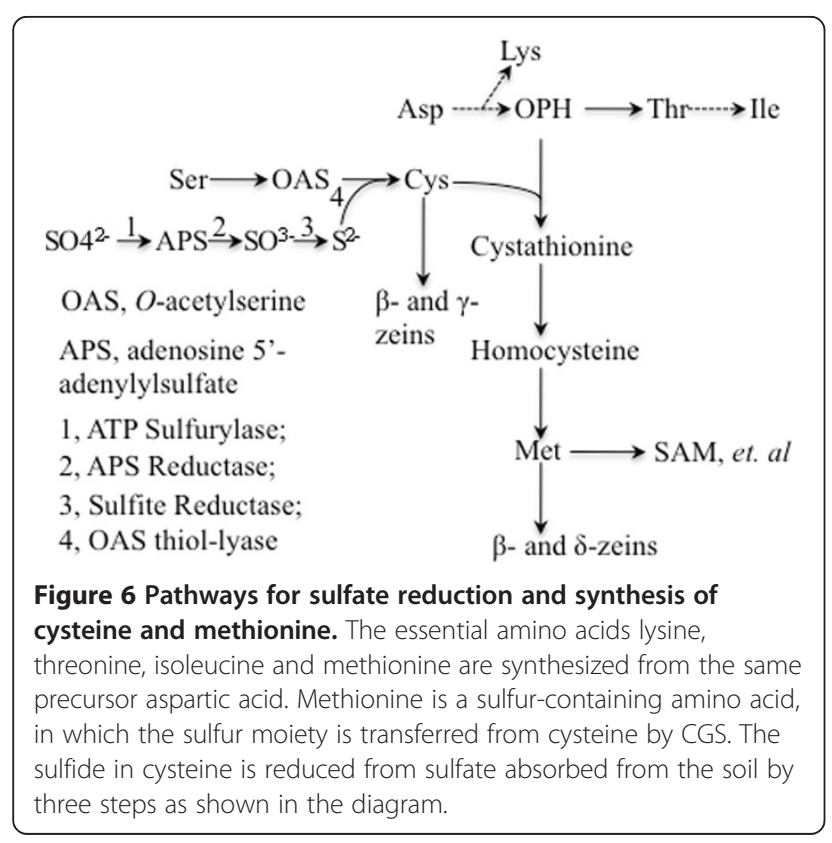

mRNA (Figure 5). Such a flow could potentially be achieved by overexpressing the committing enzyme APR or SAT during photosynthesis. Indeed, heterologous expression of bacterial APR has been shown to increase expression of the $\delta$-zein protein expression [30]. Alternative strategies for increasing cysteine biosynthesis could also be achieved with the overexpression of SAT [25].

\section{Conclusion}

In contrast to the nitrogen sink, storage of sulfur is controlled through the accumulation of a few specialized proteins in maize endosperm. We propose that $\beta$ - and $\delta$-zeins are the major sink for methionine and $\beta$ - and $\gamma$-zeins for cysteine in the seed of maize. Because methionine constitutes the endpoint of the sulfur amino acid biosynthetic pathway and the sulfur moiety goes through cysteine, increased expression of methioninerich proteins starves the accumulation of cysteine-rich proteins during endosperm development. Therefore, we hypothesize that the major bottleneck for increased seed methionine may be the reduction of sulfur in the leaves during photosynthesis. 


\section{Methods}

\section{Genetic stocks}

The $\beta R N A i, \gamma R N A i, z 1 C R N A i$, P6z1RNAi and Hi-Met transgenic plants in this work were all generated in our lab and have been described before $[8,10,14,17,24]$. Inbred line A654 is a natural null mutant for the $18-\mathrm{kDa}$ and $10-\mathrm{kDa} \delta$-zein genes. A654- $\delta$ was generated by introgressing two intact $\delta$-zein alleles from B73, whereas A654- $\beta$ RNAi, A654- $\gamma$ RNAi, and A654- $\beta \gamma$ RNAi were produced by crossing the corresponding RNAi lines with A654 first. All resulting materials were backcrossed to A654 for two generations and then selfcrossed for two or three generations to generate homozygous intact $\delta$-zein alleles. $\beta$ RNAi in A654- $\beta$ RNAi should also be homozygous because it has no phenotype. A654- $\gamma$ RNAi was semi-opaque and A654- $\beta \gamma$ RNAi completely opaque, so that A654 inheriting $\gamma$ RNAi or both $\beta$ RNAi and $\gamma$ RNAi was easy to score.

\section{Total zein and non-zein protein extraction, protein and amino acid composition analysis}

For zein extraction, the dry kernels were wrapped individually in two layers of thick aluminum foil and crushed into fine flour with a heavy hammer and immature seeds at 18 DAP were frozen in liquid nitrogen and ground in a mortar. For segregation analysis, kernels were ground individually. Only $50 \mathrm{mg}$ (mature seed) or $100 \mathrm{mg}$ (18 DAP) of flour was transferred to a $2 \mathrm{ml}$ Eppendorf tube, then mixed and vortexed with $400 \mu \mathrm{l}$ of $70 \%$ ethanol/2\% 2-mercaptoethanol (v/v), then kept on the bench at room temperature overnight; the mixture was centrifuged at $13,000 \mathrm{rpm}$ in a benchtop microfuge for $10 \mathrm{~min}$, then 100 (mature seed) or 200 (18 DAP) $\mu \mathrm{l}$ of the supernatant liquid was transferred to a new tube; $10 \mu \mathrm{l}$ of $10 \%$ SDS was added to the extract, the mixture was dried by vacuum and resuspended in $100 \mu$ of distilled water.

For extraction of non-zein from dry seeds, the supernatant from above was discarded. Solids remaining in the tube were resuspended with zein extraction buffer to completely remove the zeins from other proteins. This step was repeated for three times. At last, the residual solids were suspended in $400 \mu$ l of non-zein extraction buffer (12.5 mM sodium borate, 5\% SDS and $2 \%$ 2-mercaptoethanol ( $\mathrm{vol} / \mathrm{vol})$ ). The mixture was kept at $37^{\circ} \mathrm{C}$ for two hours and vortexed several times during this period. The mixture was centrifuged at 13,000 rpm for $10 \mathrm{~min}$, and then $100 \mu \mathrm{l}$ of the non-zein supernatant was transferred to a new tube. $4 \mu \mathrm{l}$ (equal to $500 \mu \mathrm{g}$ of flour) of each sample was analyzed with 15\% SDS-PAGE gel, run at 200 Volts for $35 \mathrm{~min}$. The resulting gel was stained with Commassie buffer.

About $20 \mathrm{~g}$ of mature seeds were ground to fine flour. The protein and amino acid composition analysis was conducted by the New Jersey Feed Laboratory, Inc., Trenton, NJ, USA.

\section{Genome-wide analysis of amino acid composition in maize protein sequences}

The Zea mays database comprises a comprehensive, high quality, and freely accessible resource of 42,654 protein sequences that were downloaded from PlantGDB http://www.plantgdb.org/search/misc/plantlistconstruction. php?mySpecies=Zea\%20mays. A self-written Perl-script was made to calculate Lys, Met, and Cys ratio in each protein sequence longer than 100 amino acids. Among 36,201 protein sequences with more than 100 amino acids, only the proteins with more than 4\% Lys, Met, or Cys were identified and counted.

\section{Acknowledgements}

We thank Jinsheng Lai for his previous invaluable work on Hi-Met maize transformation and Thomas Leustek for critical reading of the manuscript. The research described in this manuscript was supported with the Selman A. Waksman Chair in Molecular Genetics.

\section{Authors' contributions}

YW, WW and JM designed the experiments and analyzed the data. YW and JM interpreted the data and wrote the manuscript. All authors read and approved the final manuscript.

Received: 10 February 2012 Accepted: 30 May 2012

Published: 30 May 2012

\section{References}

1. Kirihara JA, Petri JB, Messing J: Isolation and sequence of a gene encoding a methionine-rich 10-kDa zein protein from maize. Gene 1988 71(2):359-370

2. Swarup S, Timmermans MC, Chaudhuri S, Messing J: Determinants of the high-methionine trait in wild and exotic germplasm may have escaped selection during early cultivation of maize. Plant J 1995, 8(3):359-368.

3. Pedersen K, Argos P, Naravana SV, Larkins BA: Sequence analysis and characterization of amaize gene encoding a high-sulfur zein protein of Mr 15,000. J Biol Chem 1986, 261(14):6279-6284.

4. Crow JF, Kermicle J: Oliver Nelson and quality protein maize. Genetics 2002, 160(3):819-821.

5. Mertz ET, Bates LS, Nelson OE: Mutant gene that changes protein composition and increases lysine content of maize endosperm. Science 1964, 145:279-280.

6. Vasal SK, Villegas E, Bjarnason M, Gelaw B, Goertz P: Genetic Modifiers and Breeding Strategies in Developing Hard Endosperm opaque 2 Materials In Improvement of Quality Traits of Maize for Grain and Silage Use. Edited by Pollmer WG, Phipps RH. London: Martinus Nijhoff; 1980:37-73.

7. Wu Y, Holding DR, Messing J: $\gamma$-Zeins are essential for endosperm modification in quality protein maize. Proc Natl Acad Sci USA 2010, 107(29):12810-12815.

8. Segal $G$, Song $R$, Messing J: A new opaque variant of maize by a single dominant RNA-interference-inducing transgene. Genetics 2003, 165 (1):387-397.

9. Huang S, Frizzi A, Florida CA, Kruger DE, Luethy MH: High lysine and high tryptophan transgenic maize resulting from the reduction of both 19- and 22-kD alpha-zeins. Plant Mol Biol 2006, 61(3):525-535.

10. Wu Y, Messing J: Novel genetic selection system for quantitative trait loci of quality protein maize. Genetics 2011, 188(4):1019-1022.

11. Cord Neto G, Yunes JA, da Silva MJ, Vettore AL, Arruda P, Leite A: The involvement of Opaque 2 on beta-prolamin gene regulation in maize and Coix suggests a more general role for this transcriptional activator. Plant Mol Biol 1995, 27(5):1015-1029.

12. Phillips RL, Morris PR, Wold F, Gengenbach BG: Seedling screening for lysine-plus-threonine resistant maize. Crop Sci 1981, 21:601-607. 
13. Phillips RL, McClure BA: Elevated protein-bound methionine in seeds of a maize line resistant to lysine plus threonine. Cereal Chem 1985, 62:213-218

14. Wu Y, Goettel W, Messing J: Non-Mendelian regulation and allelic variation of methionine-rich delta-zein genes in maize. Theor App/ Genet 2009, 119(4):721-731.

15. Bagga S, Adams HP, Rodriguez FD, Kemp JD, Sengupta-Gopalan C: Coexpression of the maize delta-zein and beta-zein genes results in stable accumulation of delta-zein in endoplasmic reticulum-derived protein bodies formed by beta-zein. Plant Cell 1997, 9(9):1683-1696.

16. Hoffman LM, Donaldson DD, Bookland R, Rashka K, Herman EM: Synthesis and protein body deposition of maize 15-kd zein in transgenic tobacco seeds. EMBO J 1987, 6(11):3213-3221.

17. Lai J, Messing J: Increasing maize seed methionine by mRNA stability. Plant J 2002, 30(4):395-402

18. Hacham Y, Matityahu I, Schuster G, Amir R: Overexpression of mutated forms of aspartate kinase and cystathionine gamma-synthase in tobacco leaves resulted in the high accumulation of methionine and threonine. Plant J 2008, 54(2):260-271.

19. Amir R: Towards improving methionine content in plants for enhanced nutritional quality. Func Plant Sci Biotech 2008, 2(1):36-46.

20. Shen B, Li C, Tarczynski MC: High free-methionine and decreased lignin content result from a mutation in the Arabidopsis S-adenosyl-Lmethionine synthetase 3 gene. Plant J 2002, 29(3):371-380.

21. Wu Y, Messing J: RNA interference can rebalance the nitrogen sink of maize seeds without losing hard endosperm. PLoS One 2012, 7(2):e32850.

22. Osborne TB: Our present knowledge of plant proteins. Science 1908, 28(718):417-427

23. Flint-Garcia SA, Bodnar AL, Scott MP: Wide variability in kernel composition, seed characteristics, and zein profiles among diverse maize inbreds, landraces, and teosinte. Theor App/ Genet 2009, 119(6):1129-1142.

24. Wu Y, Messing J: RNA interference-mediated change in protein body morphology and seed opacity through loss of different zein proteins. Plant Physiol 2010, 153(1):337-347.

25. Leustek T, Martin MN, Bick JA, Davies JP: Pathways and regulation of sulfur metabolism revealed through molecular and genetic studies. Annu Rev Plant Physiol Plant Mol Biol 2000, 51:141-165.

26. Messing J, Fisher $\mathrm{H}$ : Maternal effect on high methionine levels in hybrid corn. J Biotechnol 1991, 21:229-238.

27. Cruz-Alvarez M, Kirihara JA, Messing JW: Post-transcriptional regulation of methionine content in maize kernels. Mol Gen Genet 1991, 225:331-339.

28. Amira G, Ifat M, Tal A, Hana B, Shmuel G, Rachel A: Soluble methionine enhances accumulation of a $15 \mathrm{kDa}$ zein, a methionine-rich storage protein, in transgenic alfalfa but not in transgenic tobacco plants. J Exp Bot 2005, 56(419):2443-2452

29. Bagga S, Potenza C, Ross J, Martin MN, Leustek T, Sengupta-Gopalan C: A transgene for high methionine protein is posttranscriptionally regulated by methionine. In Vitro Cell Dev BiolPlant 2005, 41:731-741.

30. Leustek T, Tarczynski MC: Methods for modulating the levels of organic sulfur compounds in plants by transforming with (P)APS reductase DNA. US Patent 6576819. 2003.

doi:10.1186/1471-2229-12-77

Cite this article as: Wu et al:: Balancing of sulfur storage in maize seed.

BMC Plant Biology 2012 12:77.

\section{Submit your next manuscript to BioMed Central and take full advantage of:}

- Convenient online submission

- Thorough peer review

- No space constraints or color figure charges

- Immediate publication on acceptance

- Inclusion in PubMed, CAS, Scopus and Google Scholar

- Research which is freely available for redistribution 